\title{
CS-10 - "Metrópolis Colaborativas 2050" en Centroamérica, un dispositivo de desarrollo territorial e investigación para la gestión moderna, caso Guatemala
}

\author{
Towards "Collaborative Metropolises 2050" in Central America, a device of territorial \\ development and research for modern management, case of Guatemala \\ Jérémy Dupont ${ }^{1 *}$, Silvia Rosales Montano ${ }^{2}$ y Silvia García Vettorazzi ${ }^{3}$ \\ ${ }^{1-2}$ Apoyo Urbano, Francia, Urbanistica, ${ }^{3}$ Empresa de Vivienda y Desarrollo Urbano, Guatemala \\ *Autor al que se dirige la correspondencia: mcc20302050@gmail.com
}

\section{Resumen}

$\mathrm{D}$ esde los años 50, la complejidad aguda de los problemas metropolitanos ha hecho imprescindible la institucionalización de la cuestión metropolitana. Al mismo tiempo, el abismo entre su legitimidad política -conocimiento y reconocimientoy el proceso de metropolización real, cuestiona la capacidad de adaptación de la(s) escala(s) de gestión a los retos territoriales. Para ello, comprender las realidades territoriales resultantes del fenómeno de metropolización es fundamental para orientar modalidades de institucionalización metropolitana y de territorialización de la acción pública. El proceso colaborativo como método, recoge entrevistas sobre la cuestión socio-espacial y territorial-política como muestra de convergencias/divergencias de opiniones (retroprospectiva perceptiva), seguidas de retro-alimentaciones y reflexiones colectivas de expertos para plantear propuestas de acción sobre la marcha (prospectiva colaborativa), aclarando así en qué las dinámicas heredadas han permitido/ impedido la solidez de la acción pública y su coherencia a futuro. Con ello se plantea cinco desafíos 2030-2050 -2 de transformación, 3 de innovación- para una metrópolis sustentable, con una visión común a partir de consensos operacionales sobre escenarios de acción territorial que concreten dichos desafíos, respaldados por objetivos de acción pública. Se re-interroga asimismo el hecho metropolitano con respecto a los fenómenos de transición, mutación y crisis, los cuales hacen patentes oportunidades y vulnerabilidades que implican nuevas geografías e (inter-)territorialidades para abordar la resiliencia territorial. Las respuestas de territorialización de acción pública han destacado la necesidad de desarrollar líneas de investigación publico-privada a través de un "Banco de Temas y Sujetos de Investigación Metropolitana" para acompañar la gestión sustentable de los territorios futuros.

Palabras claves: Prospectiva colaborativa, gestión sustentable, Banco de Investigación Metropolitana, Laboratorio Colaborativo de Ideas y Conocimientos Metropolitanos

\section{Abstract}

Since the 1950s, the acute complexity of metropolitan concerns has made essential the institutionalization of the metro$\checkmark$ politan issue. At the same time, the mismatch between its political legitimacy - knowledge and acknowledgment - and the real metropolitan-becoming process questions the adaptation ability of management scales to the territorial challenges. For that matter, it is essential to understand the territorial realities that result from the metropolization phenomenon to guide metropolitan institutionalization modalities and the territorialization of public policy. The collaborative process as a method, collects interviews about the socio-spatial and territorial-political issue as a sample of convergences/divergences of opinions (perceptive-retroprospective approach), followed by feedback and experts' collective considerations in order to propose forms of action "on the go" (collaborative expert foresight). This method contributes to defining how the inherited dynamics have allowed/prevented solid public actions as well as its future coherence. As a result, five challenges for a sustainable metropolis 2030-2050 are presented - two transformative, three innovative-, based on a common vision from the consensus of territorial action scenarios that attempt to materialize those challenges, supported by public action purposes. The metropolitan issue is once again questioned regarding the transition, mutation and crisis phenomena, which manifest the opportunities and vulnerabilities that imply new geographies and (inter)territories, to address territorial resilience.

Key words: Metropolitan-local public action territorialization, collaborative foresight,sustainable management, Metropolitan Research Bank, Colaborative Laboratory of Metropolitan Ideas and Knowledge 